\title{
Effect of super-optimal levels of fertilizers on soil enzymatic activities during growth stages of wheat crop on an Inceptisol
}

\author{
Rajiv Rakshit ${ }^{1,2 *}$, A.K. Patra', T.J. Purakayastha', R.D. Singh ${ }^{1}$, Shiva Dhar $^{3}$, Himanshu \\ Pathak $^{4}$ and Anupam Das ${ }^{2}$ \\ ${ }^{1}$ Division of Soil Science and Agricultural Chemistry, Indian Agricultural Research Institute, New Delhi-110012 \\ INDIA \\ ${ }^{2}$ Department of Soil Science and Agricultural Chemistry, Bihar Agricultural College, BAU, Sabour- 813210, \\ (Bihar), INDIA \\ ${ }^{3}$ Division of Agronomy, Indian Agricultural Research Institute, New Delhi- 110012, INDIA \\ ${ }^{4}$ CESCRA, Indian Agricultural Research Institute, New Delhi-110012, INDIA \\ *Corresponding author. E- mail: rajiv.ssaciari@gmail.com
}

Received: November 09, 2015; Revised received: April 27, 2016; Accepted: July 28, 2016

\begin{abstract}
A field experiment was conducted during 2010-2011 and 2011-2012 to investigate the effect of optimal $(100 \% \mathrm{NPK})$ to super-optimal doses $(200 \% \mathrm{NPK})$ of mineral fertilizers on soil enzymes such as dehydrogenase (DHA), acid phosphatase (Ac-PA), alkaline phosphatase (Alk-PA), fluorescien diacetate hydrolysis (FDA), urease and nitrate reductase (NRA) at three physiological stages (CRI, anthesis and maturity) of wheat crop on an Inceptisol. Dehydrogenase activity was reduced by $28-37 \%$ when fertilizer application was at super-optimal dose (200\% NPK), whereas, urease and NRA responded positively in the range of $43-44 \%$ and $213-231 \%$ respectively. Alk-PA was $7.3-7.9 \%$ higher in treatments receiving $125 \%$ NPK as compared to control (100\% NPK); whereas, Ac-PA declines in the plots receiving 175 and $200 \%$ of recommended dose of fertilizer (RDF) as compared to $150 \%$ NPK levels. Addition of $175 \%$ RDF increased the FDA to the tune of $46-53 \%$ as compared to $100 \%$ NPK. A significant $(P \leq 0.05)$ positive interaction between fertilizer treatments and physiological stages of wheat growth was observed on soil enzyme activities (except urease and NRA) being highest at the anthesis stage of wheat. Correlation matrix analysis showed that DHA was correlated with the studied enzyme activities except Ac-PA and FDA; whereas, strong correlation was observed between urease and NRA $(r=0.981, P=0.01)$. This study provides theoretical and practical base for avoiding super optimal application of fertilisers which hinders the enzyme activities and vis-a-vis sustainable nutrient enrichment under rhizosphere.
\end{abstract}

Key words: Physiological stages, Soil enzymes, Super-optimal fertilization, Wheat

\section{INTRODUCTION}

Food grain demand of India is estimated at about 325 million tonnes per annum by 2025 , necessitating an increase of about 66 million tonnes (MT) from the fixed target of $259 \mathrm{MT}$ in 2013-2014. This increased production has to come from the same (142 Mha) or reduced agricultural area which implies intensification of the agricultural production system (Harlook, 2006). Much of the contribution in yield change in the last two decades is caused by high fertilizer usage. Fertilizer application, a primary approach for agriculture intensification, contributes to increase crop growth and food production in India. However, the effects of mineral fertilizers on soil properties, particularly on soil microbial properties, are not well understood (Mandal et al., 2007). In a soil-plant system, the soil's energy powerhouse is the rhizosphere, and thus any alteration to the fertility management (balanced or imbalanced fertilization) will have a strong impact at the soil-plant interface, and subsequently on the agricultural productivity and sustainability of the ecosystem (Mandal et al., 2007) and nutrient dynamics of the soil and plants (Mandal et al., 2009). Microbial communities are important for the functioning of the ecosystem (Patra et al., 2005), both in relation to direct interactions with plants and with regard to nutrient and organic matter cycling. Enzymes are mainly from soil microorganisms and despite their low amounts, are essential components involved in the dynamics of soil nutrient transformations (Masto et al., 2006; Ge et al., 2010). Enzymes, such as urease, phosphatase, dehydrogenase and nitrate reductase, play a crucial role in microbial activities and transformations of organic compounds (Sannino and Gianfreda, 2001). Enzyme activity in the soil environment is highly linked to overall soil microbial activity and also been proposed as indicators of fertility, soil quality and biological activities of soils (Quilchano 
and Mara ñ'on, 2002; Roldán et al., 2005). As far as soil enzymes are concerned, previous results are still inconsistent and contradictory. Moreover, the trends in soil fertility changes in many of the short-term experiments (Blaise et al., 2005) have been reported from samples obtained at the beginning or at the end of the cropping sequence. In contrast, information on the biological processes, such as soil enzymatic activity, which mediate nutrients cycling and influence their acquisition during active crop growth stages, is limited (Barnard et al., 2006). Since microbial processes are dynamic, patterns of temporal fluctuation during crop growth are of great importance in relation to the nutrient supplying capacity of the ecosystem and the crop demands (Mandal et al., 2009). Most of the information on soil enzymes was generally available under long term application of organic and inorganic amendments. This experiment examines the enzymes activity (Bio indicator) specifically under inorganic treatments, which is a reality under tropical agro-ecosystem, where organic inputs are very scanty. The present research, therefore, was undertaken to assess the impact of different levels of mineral fertilizers and physiological stages of wheat growth on soil enzymatic activities in a semi-arid, tropical agro-ecosystem.

\section{MATERIALS AND METHODS}

Experimental condition and design: The present study was undertaken at the experimental field of Indian Agricultural Research Institute, New Delhi, India. The soil was a fine loamy, mixed, slightly alkaline, moderately permeable, hyperthermic family of the Typic Haplustept (old alluvium). The general physicochemical properties of the experimental soil are presented in Table 1. Under a maize-wheat cropping system, wheat (variety HD 2687) was sown in the second week of November in each cropping season (Rabi 2010 and Rabi 2011) and harvested on $3^{\text {rd }}$ week of April, 2011 and 2012 respectively. The plot size was $20 \mathrm{~m}^{2}$. Wheat was sown manually through hand plough with row to row distance $22.5 \mathrm{~cm}$ using seed rate of $100 \mathrm{~kg} \mathrm{ha}^{-1}$. Irrigation was applied as and when required. In this study, a randomized block design was adopted in the experimental field and ten treatments with three replicates each were chosen as follows: $100 \%$ NPK $\left(\mathrm{T}_{1}\right) ; 125 \%$ NPK $\left(\mathrm{T}_{2}\right) ; 150 \%$ NPK $\left(\mathrm{T}_{3}\right)$; $175 \%$ NPK $\left(\mathrm{T}_{4}\right) ; 200 \%$ NPK $\left(\mathrm{T}_{5}\right) ; 100 \% \mathrm{NPK}+\mathrm{Fe}$ $\left(\mathrm{T}_{6}\right) ; 125 \% \mathrm{NPK}+\mathrm{Fe}\left(\mathrm{T}_{7}\right) ; 150 \% \mathrm{NPK}+\mathrm{Fe}\left(\mathrm{T}_{8}\right) ;$ $175 \% \mathrm{NPK}+\mathrm{Fe}\left(\mathrm{T}_{9}\right) ; 200 \% \mathrm{NPK}+\mathrm{Fe}\left(\mathrm{T}_{10}\right)$. The recommended dose for wheat is 120:60:40 kg N, $\mathrm{P}_{2} \mathrm{O}_{5}$ and $\mathrm{K}_{2} \mathrm{O}$ ha $^{-1}$ respectively. Full dose of $\mathrm{P}$ and $\mathrm{K}$ was applied through diammonium phosphate $(18 \% \mathrm{~N}$ and $\left.46 \% \mathrm{P}_{2} \mathrm{O}_{5}\right)$ and muriate of potash $\left(60 \% \mathrm{~K}_{2} \mathrm{O}\right)$, respectively as basal along with $1 / 3^{\text {rd }} \mathrm{N}$ was applied through diammonium phosphate and urea $(46 \% \mathrm{~N})$. Two splits of $\mathrm{N}$ was applied through urea at CRI and anthesis stage. As the available iron was found to be low under the experimental condition (Table 1), so it was essential to include the same in the applied treatments, so as to provide the plant with adequate and balance nutrients to fulfil their metabolic requirements. Three foliar sprays of $3 \% \mathrm{FeSO}_{4} .7 \mathrm{H}_{2} \mathrm{O}$ each at the rate of $500 \mathrm{~L} \mathrm{ha}^{-1}$ were applied at 40, 60, and 75 DAS of wheat. Thus, three foliar sprays required $45 \mathrm{~kg} \mathrm{FeSO}{ }_{4} .7 \mathrm{H}_{2} \mathrm{O} \mathrm{ha}^{-1}$.

Soil sampling and enzymatic assay: Soil samples were collected, from $0-15 \mathrm{~cm}$ (ploughed layer) of each treatment described above. Soils were sampled at the CRI stage, anthesis stage and the maturity stage (before harvesting) of wheat. Fresh soil samples were passed through a 2-mm sieve and conserved at $4^{\circ} \mathrm{C}$ in a refrigerator for the determination of soil enzymatic activities and are expressed in oven dry equivalent weight of soils. Dehydrogenase activity in soil was determined by the method described by Klein et al., 1971. The assay of phosphomonoesterases activity (acid and alkaline) using p-Nitrophenol as standard. The FDA (Fluorescein diacetate) hydrolysis assay was carried out using Fluorescein standard (Green et al., 2007). Soil urease activity was estimated by the spectrophotometric method (Douglas and Bremner, 1971). Urea content of the extract was obtained by measuring the absorbance of the red colour developed at $527 \mathrm{~nm}$ using spectrophotometer. Nitrate reductase activity in soil was estimated by the spectrophotometric method as given by Roberge (1978). $\mathrm{NO}_{2}^{-}-\mathrm{N}$ was estimated using spectrophotometer at $540 \mathrm{~nm}$.

Statistical analysis: Analysis of variance pertaining to two factors namely mineral fertilizers $\left(T_{1}\right.$ to $\left.T_{10}\right)$ and the various crop growth stages (CRI, Anthesis and Maturity) were calculated following standard statistical methods (Gomez and Gomez, 1984). Least significant difference (LSD at $P=0.05$ ) was used to determine whether means differed significantly. For statistical analysis of data, Microsoft Excel (Microsoft Corporation, USA) and SPSS window version 12.0 (SPSS Inc., Chicago, USA) packages were used.

\section{RESULTS AND DISCUSSION}

Dehydrogenase activity (DHA): During the present study dehydrogenase activity (DHA) in soil samples showed a significant $(\mathrm{P} \leq 0.05)$ effect of different fertilizer treatments and stages of wheat growth and their interactions (Table 2). Anthesis stage of wheat crop had the maximum impact in enhancing DHA (14.24 $\mu \mathrm{g}$ TPF produced $\mathrm{g}^{-1}$ soil $\mathrm{hr}^{-1}$ ) in the soil followed by CRI $\left(11.78 \mu \mathrm{g}\right.$ TPF produced $\mathrm{g}^{-1}$ soil $\mathrm{hr}^{-1}$ ) and maturity $\left(9.01 \mu \mathrm{g}\right.$ TPF produced $\mathrm{g}^{-1}$ soil $\left.\mathrm{hr}^{-1}\right)$. The mean values of the 2 year data were found to be $12.94 \mu \mathrm{g}$ TPF produced $\mathrm{g}^{-1}$ soil $\mathrm{hr}^{-1}$ and $13.32 \mu \mathrm{g}$ TPF produced $\mathrm{g}^{-1}$ soil $\mathrm{hr}^{-1}$ for $\mathrm{T}_{1}$ and $\mathrm{T}_{6}$ respectively (over the three crop growth stages); which were at par with all other treatments except those plots receiving $175 \%$ and $200 \%$ RDF, revealing that dose over $150 \%$ NPK deteriorates the DHA over the two cropping cycle. The two way 
Table 1. Physico-chemical properties of initial soil sample of experimental field.

\begin{tabular}{|c|c|c|}
\hline Sl. No. & Soil Properties & Values \\
\hline 1 & $\mathrm{pH}(1: 2.5$ soil to water suspension ratio) & 8.39 \\
\hline 2 & $\mathrm{EC}\left(\mathrm{dS} \mathrm{m} \mathrm{m}^{-1}\right)$ & 0.33 \\
\hline 3 & Texture & Sandy loam \\
\hline 4 & Soil Type & Typic Haplustept \\
\hline 5 & Soil organic carbon $(\%)$ & 0.34 \\
\hline 6 & Alkaline $\mathrm{KMnO}_{4}-\mathrm{N}\left(\mathrm{kg} \mathrm{ha}^{-1}\right)$ & 223.31 \\
\hline 7 & Olsens'- P $\left(\mathrm{kg} \mathrm{ha}^{-1}\right)$ & 15.19 \\
\hline 8 & Ammonium acetate- $\mathrm{K}\left(\mathrm{kg} \mathrm{ha}^{-1}\right)$ & 209.07 \\
\hline 9 & DTPA extractable $\mathrm{Zn}\left(\mathrm{mg} \mathrm{kg}^{-1}\right)$ & 0.82 \\
\hline 10 & DTPA extractable Fe $\left(\mathrm{mg} \mathrm{kg}^{-1}\right)$ & 1.38 \\
\hline 11 & DTPA extractable Mn (mg kg $\left.{ }^{-1}\right)$ & 3.61 \\
\hline 12 & DTPA extractable $\mathrm{Cu}\left(\mathrm{mg} \mathrm{kg}^{-1}\right)$ & 0.57 \\
\hline 13 & Dehydrogenase ( $\mu$ g TPF $\mathrm{g}^{-1}$ soil $\mathrm{hr}^{-1}$ ) & 3.58 \\
\hline 14 & Acid phosphatase ( $\mu \mathrm{g}^{\mathrm{PNP}} \mathrm{g}^{-1}$ soil $\left.\mathrm{hr}^{-1}\right)$ & 9.24 \\
\hline 15 & Alkaline phosphatase ( $\mu \mathrm{g} \mathrm{PNP} \mathrm{g}^{-1}$ soil $\mathrm{hr}^{-1}$ ) & 99.54 \\
\hline 16 & FDA ( $\mu$ g fluorescein produced $\mathrm{g}^{-1}$ soil $\mathrm{hr}^{-1}$ ) & 15.13 \\
\hline 17 & Urease $\left(\mu \mathrm{g}\right.$ urea-N released $\mathrm{g}^{-1}$ soil $\left.\mathrm{hr}^{-1}\right)$ & 9.21 \\
\hline 18 & NRA $\left(\mu \mathrm{g} \mathrm{NO}_{2}^{-}\right.$produced $\left.\mathrm{g}^{-1} \mathrm{~d}^{-1}\right)$ & 0.09 \\
\hline
\end{tabular}

Table 2. Mean activity of dehydrogenase ( $\mu \mathrm{g}$ TPF produced $\mathrm{g}^{-1}$ soil $\mathrm{hr}^{-1}$ ) (data pooled from two cropping season) as affected by various levels of mineral fertilization and physiological stages of wheat growth.

\begin{tabular}{ccccc}
\hline Treatment & CRI & Anthesis & Maturity & Mean \\
\hline $\mathrm{T}_{1}$ & 13.01 & 16.01 & 9.81 & 12.94 \\
$\mathrm{~T}_{2}$ & 13.06 & 15.53 & 9.42 & 12.67 \\
$\mathrm{~T}_{3}$ & 12.04 & 14.54 & 9.12 & 11.90 \\
$\mathrm{~T}_{4}$ & 10.61 & 13.49 & 8.58 & 10.89 \\
$\mathrm{~T}_{5}$ & 10.02 & 12.29 & 7.88 & 10.06 \\
$\mathrm{~T}_{6}$ & 13.27 & 16.01 & 10.67 & 13.32 \\
$\mathrm{~T}_{7}$ & 13.30 & 15.30 & 9.00 & 12.53 \\
$\mathrm{~T}_{8}$ & 12.20 & 14.49 & 9.16 & 11.95 \\
$\mathrm{~T}_{9}$ & 10.38 & 13.19 & 8.82 & 10.80 \\
$\mathrm{~T}_{10}$ & 9.89 & 11.59 & 7.63 & 9.70 \\
Mean & 11.78 & 14.24 & 9.01 & \\
$\mathrm{CD}$ & \multicolumn{5}{c}{$\mathrm{T}=1.76$} & $\mathrm{~S}=2.14$ & $\mathrm{TXS}=2.33$ \\
\hline \multicolumn{5}{c}{}
\end{tabular}

Table 4. Mean activity of alkaline phosphates ( $\mu \mathrm{g}$ PNP produced $\mathrm{g}^{-1}$ soil $\mathrm{hr}^{-1}$ ) (data pooled from two cropping season) as affected by various levels of mineral fertilization and physiological stages of wheat growth.

\begin{tabular}{cllll}
\hline Treatment & CRI & Anthesis & Maturity & Mean \\
\hline $\mathrm{T}_{1}$ & 167.17 & 217.06 & 154.39 & 179.54 \\
$\mathrm{~T}_{2}$ & 185.34 & 232.31 & 160.55 & 192.73 \\
$\mathrm{~T}_{3}$ & 157.47 & 208.29 & 149.30 & 171.69 \\
$\mathrm{~T}_{4}$ & 145.00 & 197.96 & 134.35 & 159.10 \\
$\mathrm{~T}_{5}$ & 133.14 & 184.41 & 125.90 & 147.82 \\
$\mathrm{~T}_{6}$ & 164.66 & 210.72 & 154.08 & 176.49 \\
$\mathrm{~T}_{7}$ & 180.10 & 230.52 & 160.70 & 190.44 \\
$\mathrm{~T}_{8}$ & 158.39 & 208.75 & 150.70 & 172.61 \\
$\mathrm{~T}_{9}$ & 145.61 & 206.59 & 133.53 & 161.91 \\
$\mathrm{~T}_{10}$ & 134.06 & 189.96 & 128.12 & 150.71 \\
Mean & 157.09 & 208.66 & 145.16 & \\
$\mathrm{CD}$ & \multicolumn{5}{c}{$\mathrm{T}=11.99$} & $\mathrm{~S}=10.08$ & $\mathrm{TXS}=15.45$ \\
\hline
\end{tabular}

interaction between crop growth stages and treatments was found to be significant $(\mathrm{P} \leq 0.05)$. Highest $\mathrm{DHA}$ was observed in anthesis stage could be attributed due to higher flux of root exudates, secretions, mucigel, mucilage, etc. in the rhizosphere and their long resi-
Table 3. Mean activity of acid phosphates ( $\mu \mathrm{g}$ PNP produced $\mathrm{g}^{-1}$ soil $\mathrm{hr}^{-1}$ ) (data pooled from two cropping season) as affected by various levels of mineral fertilization and physiological stages of wheat growth.

\begin{tabular}{ccccc}
\hline Treatment & CRI & Anthesis & Maturity & Mean \\
\hline $\mathrm{T}_{1}$ & 16.68 & 20.90 & 15.76 & 17.78 \\
$\mathrm{~T}_{2}$ & 27.92 & 30.08 & 26.66 & 28.22 \\
$\mathrm{~T}_{3}$ & 35.78 & 40.24 & 35.01 & 37.01 \\
$\mathrm{~T}_{4}$ & 33.90 & 37.53 & 30.76 & 34.06 \\
$\mathrm{~T}_{5}$ & 26.47 & 31.80 & 26.97 & 28.41 \\
$\mathrm{~T}_{6}$ & 18.56 & 23.85 & 17.88 & 20.10 \\
$\mathrm{~T}_{7}$ & 30.02 & 33.20 & 28.88 & 30.70 \\
$\mathrm{~T}_{8}$ & 35.76 & 39.67 & 35.30 & 36.91 \\
$\mathrm{~T}_{9}$ & 34.92 & 38.91 & 34.02 & 35.95 \\
$\mathrm{~T}_{10}$ & 27.43 & 35.07 & 27.45 & 29.98 \\
Mean & 28.74 & 33.13 & 27.87 \\
$\mathrm{CD}$ & \multicolumn{5}{c}{$\mathrm{T}=4.79$} & $\mathrm{~S}=3.55$ & $\mathrm{TXS}=\mathrm{NS}$ \\
\hline \multicolumn{5}{c}{}
\end{tabular}

Table 5. Mean activity of FDA ( $\mu$ g fluorescein produced $\mathrm{g}^{-1}$ soil $\mathrm{hr}^{-1}$ ) (data pooled from two cropping season) as affected by various levels of mineral fertilization and physiological stages of wheat growth.

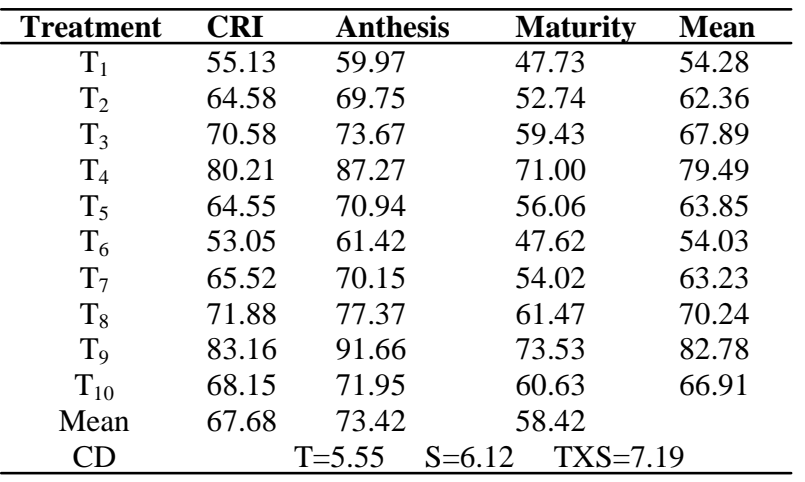

dent time (Rakshit et al., 2012). Conventional practices like high fertilization exhibited the lowest enzyme activity on each sampling date and the probable reason may be the inhibition of enzyme synthesis by inorganic ions (Okur et al., 2009). In some studies, DHA in- 
Table 6. Mean activity of urease ( $\mu \mathrm{g}$ urea-N released $\mathrm{g}^{-1}$ soil $\mathrm{hr}^{-1}$ ) (data pooled from two cropping season) as affected by various levels of mineral fertilization and physiological stages of wheat growth.

\begin{tabular}{cllll}
\hline Treatment & CRI & Anthesis & Maturity & Mean \\
\hline $\mathrm{T}_{1}$ & 47.53 & 43.71 & 35.13 & 42.12 \\
$\mathrm{~T}_{2}$ & 52.29 & 48.06 & 38.59 & 46.31 \\
$\mathrm{~T}_{3}$ & 52.29 & 54.54 & 45.39 & 50.74 \\
$\mathrm{~T}_{4}$ & 64.98 & 56.22 & 47.67 & 56.29 \\
$\mathrm{~T}_{5}$ & 70.73 & 60.22 & 49.94 & 60.30 \\
$\mathrm{~T}_{6}$ & 46.67 & 43.52 & 34.16 & 41.45 \\
$\mathrm{~T}_{7}$ & 49.69 & 45.04 & 39.67 & 44.80 \\
$\mathrm{~T}_{8}$ & 59.31 & 52.44 & 42.86 & 51.54 \\
$\mathrm{~T}_{9}$ & 61.56 & 61.97 & 49.55 & 57.69 \\
$\mathrm{~T}_{10}$ & 67.89 & 61.14 & 50.50 & 59.84 \\
Mean & 57.29 & 52.69 & 43.35 \\
$\mathrm{CD}$ & \multicolumn{5}{c}{$\mathrm{T}=6.73$} & $\mathrm{~S}=5.34$ & $\mathrm{TXS}=\mathrm{NS}$ \\
\hline
\end{tabular}

Table 7. Mean activity of nitrate reductase $\left(\mu \mathrm{g} \mathrm{NO}{ }_{2}^{-}\right.$produced $\mathrm{g}^{-1} \mathrm{~d}^{-1}$ ) (data pooled from two cropping season) as affected by various levels of mineral fertilization and physiological stages of wheat growth.

\begin{tabular}{cllll}
\hline Treatment & CRI & Anthesis & Maturity & Mean \\
\hline $\mathrm{T}_{1}$ & 2.30 & 0.71 & 0.01 & 1.01 \\
$\mathrm{~T}_{2}$ & 3.99 & 0.71 & 0.01 & 1.57 \\
$\mathrm{~T}_{3}$ & 4.92 & 0.99 & 0.01 & 1.97 \\
$\mathrm{~T}_{4}$ & 7.45 & 1.09 & 0.01 & 2.85 \\
$\mathrm{~T}_{5}$ & 8.85 & 1.18 & 0.01 & 3.35 \\
$\mathrm{~T}_{6}$ & 2.12 & 0.90 & 0.01 & 1.01 \\
$\mathrm{~T}_{7}$ & 4.18 & 0.81 & 0.01 & 1.67 \\
$\mathrm{~T}_{8}$ & 4.64 & 1.18 & 0.01 & 1.94 \\
$\mathrm{~T}_{9}$ & 7.27 & 0.81 & 0.01 & 2.70 \\
$\mathrm{~T}_{10}$ & 9.04 & 0.99 & 0.01 & 3.35 \\
Mean & 5.48 & 0.94 & 0.01 & \\
$\mathrm{CD}$ & \multicolumn{5}{c}{$\mathrm{T}=0.39$} & $\mathrm{~S}=0.21$ & $\mathrm{TXS}=0.67$ \\
\hline \multicolumn{5}{c}{}
\end{tabular}

Table 8. Correlation matrix ( $r$ values) for soil enzyme activities during wheat growth. $* * *$ Marked correlations are significant at $P=0.05$ and 0.01 , respectively. ( $n=60$, data pooled from all three stages). NS, not significant at $P=0.05$.

\begin{tabular}{ccccccc}
\hline Variables & DHA & Ac-PA & Alk-PA & FDA & Urease & NRA \\
\hline DHA & 1.00 & - & - & - & - & - \\
Ac-PA & $-0.469^{\mathrm{NS}}$ & 1.00 & - & - & - & - \\
Alk-PA & $0.889^{* *}$ & $-0.253^{\mathrm{NS}}$ & 1.00 & - & - & - \\
FDA & $-0.594^{\mathrm{NS}}$ & $0.829^{* *}$ & $-0.439^{\mathrm{NS}}$ & 1.00 & - & - \\
Urease & $0.978^{* *}$ & $0.589^{\mathrm{NS}}$ & $0.870^{* *}$ & $0.700^{*}$ & 1.00 & - \\
NRA & $0.989^{* *}$ & $0.519^{\mathrm{NS}}$ & $0.858^{* *}$ & $0.629^{\mathrm{NS}}$ & $0.981^{* *}$ & 1.00 \\
\hline
\end{tabular}

creased with $\mathrm{N}$ fertilization levels. This could be due to increased availability of energy source for the microbial activity especially the anaerobes. Our report contradicts the results from Trevors (1984) who observed the positive effect of higher $\mathrm{N}$ on the increased dehydrogenase activity.

Acid phosphatase activity (Ac-PA): The data showed on Ac-PA suggests that the values were significantly $(\mathrm{P} \leq 0.05)$ affected by fertilization. Mean values for the treatments for Ac-PA ranged from $17.78 \mu \mathrm{g}$ PNP produced $\mathrm{g}^{-1}$ soil $\mathrm{hr}^{-1}$ in control $(100 \% \mathrm{NPK})$ to $37.01 \mu \mathrm{g}$ PNP produced $\mathrm{g}^{-1}$ soil $\mathrm{hr}^{-1}$ (150\% NPK) (Table 3).

Crop growth stage effects on Ac-PA were significant $(\mathrm{P} \leq 0.05)$, and the values were found to be higher in the anthesis stage, that is $\left(33.13 \mu \mathrm{g}\right.$ PNP produced $\mathrm{g}^{-1}$ soil $\mathrm{hr}^{-1}$ ) reflecting anthesis as the most conspicuous stage for the higher activity of Ac-PA, which was followed by CRI $\left(28.74 \mu \mathrm{g}\right.$ PNP produced $\mathrm{g}^{-1}$ soil $\left.\mathrm{hr}^{-1}\right)$ and maturity $\left(27.87 \mu \mathrm{g}\right.$ PNP produced $\mathrm{g}^{-1}$ soil $\left.\mathrm{hr}^{-1}\right)$. Fertilization with $\mathrm{N}$ increased Ac-PA (Graham and Haynes, 2005). We observed a similar trend, but with significant decline at the super optimal dose of $200 \%$ NPK. Addition of phosphorus through mineral fertilisers influences the acid phosphatase activity that is governed by both plant root and rhizospheric microorganism. Root biomass increases with the application of higher level of mineral fertiliser (Rakshit et al., 2016), hence higher Ac-PA (Wen-Hui et al., 2007). Higher root biomass promotes microbial density that creates a severe thrust for native phosphorus demand. A negative feedback mechanism suppressed the Ac-PA at higher P supply (Olander and Vitousek, 2000), because of the inverse relationship phosphatase enzyme activity and $\mathrm{P}$ demand (Clarholm 1993).

Alkaline phosphatase activity (Alk-PA): The results indicated statistically significant $(\mathrm{P} \leq 0.05)$ differences in the level of Alk-PA in the soil between various levels of fertilization (Table 4). In contrary to the values of Ac-PA as affected by fertilization, Alk-PA responded in a different manner. The higher values were associated with the $\mathrm{T}_{2}\left(192.73 \mu \mathrm{g}\right.$ PNP produced $\mathrm{g}^{-1}$ soil $\left.\mathrm{hr}^{-1}\right)$ and $\mathrm{T}_{7}\left(190.44 \mu \mathrm{g}\right.$ PNP produced $\mathrm{g}^{-1}$ soil $\left.\mathrm{hr}^{-1}\right)$ treatments representing $125 \% \mathrm{RDF}$; whereas additional fertilizers lead to a decline in the activity of AlkPA. Alk-PA at different crop growth stages exhibited a similar pattern as that of Ac-PA; reflecting higher values at anthesis $\left(208.66 \mu \mathrm{g}\right.$ PNP produced $\mathrm{g}^{-1}$ soil $\mathrm{hr}^{-1}$ ) and lower at maturity stage $(145.16 \mu \mathrm{g}$ PNP produced $\mathrm{g}^{-1}$ soil $\left.\mathrm{hr}^{-1}\right)$. The interaction effect between treatments and crop growth stages was found to be significant $(\mathrm{P} \leq 0.05)$ and higher Alk-PA $(232.31 \mu \mathrm{g}$ PNP produced $\mathrm{g}^{-1}$ soil $\mathrm{hr}^{-1}$ ) was observed due to interactive effect of $125 \%$ NPK treatment and anthesis stage. In the present study we observed a declining trend after the application of $125 \%$ NPK and can be explained by the inhibition of phosphatase synthesis by available $\mathrm{P}$ as observed by other (Speir and Cowling, 1991). When nutrient availability is low, the biota may be able to increase production of these enzymes to enhance the supply of inorganic nutrients (Olander and Vitousek, 2000). P availability was more in N-fertilized plots, and thus microbes do not produced more phosphatase, which could cleave phosphate groups from the exterior of complex organic molecules, resulting in further in- 
crease in phosphatase activity.

Fluorescein diacetate hydrolysis (FDA): Distinct differences in fluorescien diacetate hydrolysis (FDA) content with values lying between $54.03 \mu \mathrm{g}$ fluorescein produced $\mathrm{g}^{-1}$ soil $\mathrm{hr}^{-1}$ in $\mathrm{T}_{6}$ and $82.78 \mu \mathrm{g}$ fluorescein produced $\mathrm{g}^{-1}$ soil $\mathrm{hr}^{-1}$ in $\mathrm{T}_{9}$ were observed in correspondence to the different treatments (Table 5). Among the exclusive mineral fertilizer treatments, the $100 \%$ NPK treatment recorded the lowest FDA (54.28 and 54.03 $\mu \mathrm{g}$ fluorescein produced $\mathrm{g}^{-1}$ soil $\mathrm{hr}^{-1}$ at $\mathrm{T}_{1}$ and $\mathrm{T}_{6}$ respectively) considering all the stages of crop growth. FDA hydrolysis activity decreased under mineral NPK fertilization, suggesting a negative impact of intensive fertilization on soil microbiological activity according to Stark et al., (2007). Our results behave in a different manner, and the decline was observed at $200 \%$ NPK levels, which calls for long term experiments exclusively with mineral fertilizers, especially in India, where farmers are totally dependent on chemical fertilizers. Results indicated the prominent impact of physiological growth stages on the FDA activity, revealing the higher values at anthesis stage $(73.42 \mu \mathrm{g}$ fluorescein produced $\mathrm{g}^{-1}$ soil $\mathrm{hr}^{-1}$ ) followed by CRI $\left(67.68 \mu \mathrm{g}\right.$ fluorescein produced $\mathrm{g}^{-1}$ soil $\mathrm{hr}^{-1}$ ) and maturity $\left(58.42 \mu \mathrm{g}\right.$ fluorescein produced $\mathrm{g}^{-1}$ soil $\left.\mathrm{hr}^{-1}\right)$ over the two cropping season. Data pertaining to the two way interaction between stage and treatment was also found to be significant $(\mathrm{P} \leq 0.05)$ and it was found to be highest for $\mathrm{T}_{4}\left(87.27 \mu \mathrm{g}\right.$ fluorescein produced $\mathrm{g}^{-1}$ soil $\left.\mathrm{hr}^{-1}\right)$ and $\mathrm{T}_{9}\left(91.66 \mu \mathrm{g}\right.$ fluorescein produced $\mathrm{g}^{-1}$ soil $\mathrm{hr}^{-}$ $\left.{ }^{1}\right)$ treatments at anthesis stage of crop growth.

Urease activity: Unlike other enzymes, urease activity was higher in soils treated with super optimal dose of NPK (Table 6). It was found to be higher for $T_{5}(60.30$ $\mu \mathrm{g}$ urea-N released $\mathrm{g}^{-1}$ soil $\left.\mathrm{hr}^{-1}\right)$ and $\mathrm{T}_{10}(59.84 \mu \mathrm{g}$ urea$\mathrm{N}$ released $\mathrm{g}^{-1}$ soil $\mathrm{hr}^{-1}$ ) treatments. Considering the stages, the higher values were obtained at CRI stage (57.29 $\mu \mathrm{g}$ urea-N released $\mathrm{g}^{-1}$ soil $\mathrm{hr}^{-1}$ ) followed by anthesis (52.69 $\mu \mathrm{g}$ urea-N released $\mathrm{g}^{-1}$ soil $\mathrm{hr}^{-1}$ ) and maturity $\left(43.35 \mu \mathrm{g}\right.$ urea-N released $\mathrm{g}^{-1}$ soil $\left.\mathrm{hr}^{-1}\right)$. Our results contradict the report which explained that urea hydrolysis was influenced by the crop growth stage with the maximum activity being recorded at the maturity stage (Nayak et al., 2007). The two way interaction between treatment and stages of crop was found to be non-significant. In contrast to the other enzymes (DHA, Ac-PA, Alk-PA and FDA) studied, urease activity followed a linear increase with the increase in mineral nitrogen fertilizers. Our results confirm the finding of Saha et al., 2008 which reported higher urease activity in plots receiving higher amount of nitrogen in mineral form.

Nitrate reductase activity (NRA): Results from present experiment demonstrated that NRA increased with the increment of fertilizers from $T_{1}$ to $T_{5}$ or from $T_{6}$ to $\mathrm{T}_{10}$. Higher values of NRA were associated with $\mathrm{T}_{5}$ and $\mathrm{T}_{10}\left(3.35 \mu \mathrm{g} \mathrm{NO}_{2}^{-}\right.$produced $\mathrm{g}^{-1}$ soil $\left.\mathrm{d}^{-1}\right)$ treatments
(Table 7). In terms of the growing stages, the highest values for NRA were observed during the Crown Root Initiation (CRI) stage of wheat growth. The differences observed during the anthesis and maturity stages of vegetation were also found to be statistically significant $(\mathrm{P} \leq 0.05)$. The highest values were associated with CRI stage (5.48 $\mu \mathrm{g} \mathrm{NO}_{2}^{-}$produced $\mathrm{g}^{-1}$ soil $\mathrm{d}^{-1}$ ) and it almost declines to very low level at maturity stage $\left(0.01 \mu \mathrm{g} \mathrm{NO}_{2}^{-}\right.$produced $\mathrm{g}^{-1}$ soil d $\left.{ }^{-1}\right)$. For NRA, significant $(\mathrm{P} \leq 0.05)$ interaction between treatment and growth stages was also observed. Interaction effect was most conspicuous at CRI stage. Higher NRA value was found to be at $9.04 \mu \mathrm{g} \mathrm{NO}_{2}^{-}$produced $\mathrm{g}^{-1}$ soild $\mathrm{d}^{-1}$ for $\mathrm{T}_{10}$ treatment $(200 \% \mathrm{NPK})$ during the CRI stage. As expected, soil $\mathrm{N}$ decreased progressively with plant growth with the highest soil $\mathrm{N}$ content observed in the samples collected at the CRI stage (data not presented). Reduction in NRA at maturity may be attributed to the decreased $\mathrm{NO}_{3}{ }^{-} \mathrm{N}$ availability (data not presented) with the progressive growth of wheat plants (Rakshit et al., 2012), and in the meantime, nitrate leaching loss and ammonia volatilization occurs (Ge et al., 2010).

Correlation matrix: A correlation matrix (Table 8) showed the existence of some significant relationships $(P=0.01)$ among the enzyme activities studied. DHA was correlated with other enzymes except Ac-PA and FDA. Ac-PA was only correlated with FDA ( $r=0.829, P=0.01)$. There exist a strong correlation between urease and NRA $(r=0.981, P=0.01)$ as presented in Table 8 .

\section{Conclusion}

The present study concluded that soil enzymatic activity varied significantly $(\mathrm{P} \leq 0.05)$, depending upon the level of fertilization and crop phenology. Enzyme activities or response could be a suitable indicators / predictors to characterize the effects of fertilizer management practices on soil biological productivity and sustainability. Our results confirm that excessive fertilizer application caused significant depression in the soil enzymatic activities irrespective of growing stages of wheat. Efforts should be made to further clarify the intrinsic mechanism of changes in activities of the enzymes in response to addition of super-optimal fertilizer, especially on long term basis. This study provides theoretical and practical base for avoiding super optimal application of fertilisers which hinders the enzyme activities and vis-à-vis sustainable nutrient enrichment under rhizosphere.

\section{ACKNOWLEDGEMENTS}

Financial assistance by Indian Agricultural Research Institute, New Delhi, in form of Senior Research Fellowship awarded to Rajiv Rakshit during the course of this investigation is gratefully acknowledged. Authors are thankful to the Director, Indian Agricultural Research Institute, New Delhi, for providing the necessary facilities for the successful completion of the work. 


\section{REFERENCES}

Barnard, R., Le Roux, X., Hungate, B.A., Cleland, E.E., Blankinship, J.C., Barthes, L. and Leadley, P.W. (2006). Several components of global change alter nitrifying and denitrifying activities in an annual grassland. Funct. Ecol. 20: 557-564.

Blaise, D., Singh, J.V., Bonde, A.N., Tekale, K.U. and Mayee, C.D. (2005). Effects of farmyard manure and fertilizers on yield, fibre quality and nutrient balance of rainfed cotton (Gossypium hirsutum). Bioresour. Technol. 96: 345-349.

Clarholm, M. (1993) Microbial biomass P, labile P, and acid phosphatase activity in the humus layer of a spruce forest, after repeated additions of fertilizers. Biol. Fertil. Soils 16:287-292

Douglas, L.A. and Bremner, J.M. (1971). A rapid method of evaluating different compounds as inhibitors of urease activity in soils. Soil Biol. Biochem. 3: 309-315.

Ge, G., Li, Z., Fan, F., Chu, G., Hou, Z. and Liang, Y. (2010). Soil biological activity and their seasonal variations in response to long-term application of organic and inorganic fertilizers. Plant Soil. 326: 31-44.

Gomez, K.A. and Gomez, A.A. (1984). Statistical Procedures for Agricultural Research. John Wiley and Sons, New York.

Graham, M.H. and Haynes, R.J. (2005). Organic matter accumulation and fertilizer-induced acidification interact to affect soil microbial and enzyme activity on a longterm sugarcane management experiment. Biol. Fert. Soils. 41: 249-256.

Green, V.S., Stott, D.E. and Diack, M. (2007). Assay of fluorescien diacetate hydrolytic activity: optimization for soil sample. Soil Biol. Biochem. 38: 693-701.

Harlook, K. (2006). PAU Honours, The Ludhiana Tribune, March 9, Chandigarh

Klein, D.A., Loh, T.C. and Goulding, R.L. (1971). A rapid procedure to evaluate dehydrogenase activity of soils low in organic matter. Soil Biol. Biochem. 3: 385-387.

Mandal, A., Patra, A.K., Singh, D., Swarup, A. and Masto, R.E. (2007). Effect of long-term application of manure and fertilizer on biological and biochemical activities in soil during crop development stages. Bioresour. Technol. 98: 3585-3592.

Mandal, A., Patra, A.K., Singh, D., Swarup, A., Purakayastha, T.J. and Masto, R.E. (2009). Effects of longterm organic and chemical fertilization on $\mathrm{N}$ and $\mathrm{P}$ in wheat plants and in soil during crop growth. Agrochimica. 53: 79-91.

Masto, R.E., Chhonkar, P.K., Singh, D. and Patra, A.K. (2006). Changes in soil biological and biochemical characteristics in a long-term field trial on a sub-tropical inceptisol. Soil Biol. Biochem. 38: 1577-1582.

Nayak, D.R., Babu, Y.J. and Adhya, T.K. (2007). Long-term application of compost influences microbial biomass and enzyme activities in a tropical Aeric Endoaquept planted to rice under flooded condition. Soil Biol. Bio- chem. 39: 1897-1906.

Okur, N., Altindisli, A., Cengel, M., Gocmez, S. and Kayikcioglu, H.H. (2009). Microbial biomass and enzyme activity in vineyard soils under organic and conventional farming systems. Turk. J. Agric. For. 33: 413-423.

Olander, L.P. and Vitousek, P.M. (2000). Regulation of soil phosphatase and chitinase activity by $\mathrm{N}$ and $\mathrm{P}$ availability. Biogeochemistry. 49: 175-190.

Patra, A.K., Abbadie, L., Clays-Josserand, A., Degrange, V., Grayston, S.J., Loiseau, P., Louault, F., Mahmood, S., Nazaret, S., Philippot, L., Poly, F., Prosser, J.I., Richaume, A. and Le Roux, X. (2005). Effect of grazing on microbial functional groups involved in soil $\mathrm{N}$ dynamics. Ecol. Monogr. 75: 65-80.

Quilchano, C. and Mara n’on, T. (2002). Dehydrogenase activity in Mediterranean forest soils. Biol. Fert. Soils. 35: 102-107.

Rakshit, R., Patra, A.K., Pal, D., Kumar, M. and Singh, R. (2012). Effect of elevated $\mathrm{CO}_{2}$ and temperature on nitrogen dynamics and microbial activity during wheat (Triticum aestivum L.) growth on a subtropical inceptisol in India. J. Agron. Crop Sci. 198: 452-465.

Rakshit, R., Patra, A.K., Purakayastha, T.J., Singh, R.D., Pathak, H., Dhar, S. and Das, A. (2016). Super-optimal fertilization affects root growth and soil microbial abundance and biomass during wheat growth. J. Food Agric. Environ. 14: 112-118.

Roberge, M.R. (1978). Methodology of soil enzyme measurement and extraction. In: R.G.Burn (Ed.), Soil Enzymes. Academic Press, pp.350.

Roldán, A., Salinas-García, J.R., Alguacil, M.M., Díaz, E. and Caravaca, F. (2005). Soil enzyme activities suggest advantages of conservation tillage practices in sorghum cultivation under subtropical conditions. Geoderma. 129: $178-185$.

Saha, S., Gopinath, K.A., Mina, B.L. and Gupta, H.S. (2008). Influence of continuous application of inorganic nutrients to a maize-wheat rotation on soil enzyme activity and grain quality in a rainfed Indian soil. Eur. $J$. Soil Biol. 44: 521-531.

Sannino, F. and Gianfreda, L. (2001). Pesticide influence on soil enzymatic activities. Chemosphere. 45: 417-425.

Speir, T.W. and Cowling, J.C. (1991). Phosphatase activities of pasture plants and soils: relationship with plant productivity and soil $\mathrm{P}$ fertility induces. Biol. Fert. Soils. 12: 189-194.

Stark, C., Condron, L.M., Stewart, A., Di, H.J. and O'Callaghan, M. (2007). Effects of past and current crop management on soil microbial biomass and activity. Biol. Fert. Soils. 43: 531-540.

Trevors, J.T. (1984). Effect of substrate concentrations, inorganic $\mathrm{NO}_{3}^{-}-\mathrm{N}$, temperature and $\mathrm{pH}$ on dehydrogenase activity in soil. Plant Soil. 77: 284-293.

Wen-Hui, Z., Zu-Cong, C. and He, Z. (2007). Effects of long term application of inorganic fertilizers on biochemical properties of a rice-planting red soil. Pedosphere. 17: 419-428. 